\title{
Physicochemical and Sensory Characteristics of Green Coconut (Cocos nucifera L.) Water Kefir
}

\author{
Bambang Dwiloka $^{\mathrm{a}^{*}}$, Heni Rizqiatia ${ }^{\mathrm{a}}$, And Bhakti Etza Setiani ${ }^{\mathrm{a}}$

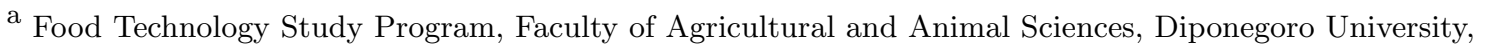 \\ Semarang \\ ${ }^{*}$ Corresponding author \\ bambangdwilokaundip@gmail.com \\ TEL: +62-81565-0-4564 \\ FAX: $+62-81565-0-4564$
}

Received: 29 July 2019; Published online: 18 October 2020

\begin{abstract}
This research aims to examine the effects of fermentation time on the physicochemical and sensory characteristics of green coconut water kefir in order to determine the optimal fermentation time based on the resulting sensory attributes. There were four fermentation time treatments $(12,24,36$, and 48 hours), each with five replications. The materials used were green coconut water and $5 \%$ kefir grains. Physical analyses included $\mathrm{pH}$ and viscosity, while the chemical analyses included total dissolved solids (TDS), alcohol content, water content, protein content and fat content. Sensory attributes included sourness, soda sensation, sour aroma, viscosity and turbidity. The results showed that fermentation time had significant effects on $\mathrm{pH}$, TDS, alcohol content, water content, protein content and the sensory attributes of green coconut water kefir. Viscosity and fat content were not affected by fermentation time. The ideal fermentation time was 12 hours resulting in a pH level of 4.6, viscosity of 0.09, TDS of $3.8^{\circ}$ Brix, alcohol content of $1.16 \%$, water content of $97.14 \%$, protein content of $6.64 \%$ and fat content of $1.17 \%$. Sensory evaluation found a low level of sourness, low soda sensation, high sour aroma, high viscosity and low turbidity.
\end{abstract}

Keywords: Fermentation; Green coconut; Physicochemical; Sensory; Water kefir

\section{Introduction}

Coconut (Cocos nucifera) is one of the palm tree species which is widely cultivated in tropical regions, especially in areas near beaches (Chidambaram, Singaraja, Prasanna, Ganesan \& Sundararajan, 2013). There are many varieties of coconut such as green dwarf, yellow dwarf and red dwarf. Green dwarf or green coconut (C. nucifera L.) is the most utilized variety of coconut due to its high content of total phenols and ascorbic acid (Santos et al., 2013). Indonesia is the largest producer of green coconut in the world, with the highest diversity (Kailaku, Syah,
Risfaheri, Setiawan \& Sulaeman, 2015; Pandin, 2015). The edible part of the fruit consists of coconut meat and coconut water (Yong, Ge, Ng \& Tan, 2009). Recently, the green coconut water market has grown rapidly in the functional beverages category due to its hydration qualities (Marsh, Hill, Ross \& Cotter, 2014). Furthermore, green coconut water contains micronutrients such as inorganic ions and vitamins that are beneficial in promoting the human body's antioxidant system (Evans \& Halliwell, 2001; Yong et al., 2009), antimicrobial peptides (Mandal et al., 2009), catechins and epicatechins (Chang \& $\mathrm{Wu}, 2011)$. Green coconut water is also a rich 
source of cytokinin that has antiaging properties in human skin cells (Ge et al., 2006).

Green coconut water is widely consumed in its natural form (Franco, Yamamoto, Tadini \& Gut, 2015 ) or in a processed, ready-to-drink beverage form (Santana, Ribeiro \& Iguti, 2011). Heat treatment is used in commercial coconut water manufacture so as to prevent microbial spoilage and oxidative enzymatic (Tan, Cheng, Bhat, Rusul \& Easa, 2014). However, heat treatment often leads to changes in the product's organoleptic and nutritional quality (Cappelletti et al., 2015). Therefore, an innovative approach is required to develop new products based on green coconut water.

Fermentation is one of food preservation methods which can improve the nutritional value of food (Marsh et al., 2014). Green coconut water contains sugars, proteins, free amino acids and minerals (Flávera et al., 2015) thus it is possible to process it into a fermented non-dairy beverage such as water kefir. Water kefir is obtained by fermenting water sucrose with kefir grains containing lactic acid bacteria and yeast (Marsh, O'Sullivan, Hill, Ross \& Cotter, 2013), resulting in a beverage with effervescent characteristics (Ismaiel, Ghaly \& El-Naggar, 2011; Liu \& Lin, 2000).

The characteristics of a fermented product are influenced by fermentation time. As there was no reported work, it was necessary to analyze the effect of fermentation time on the physicochemical and sensory properties of green coconut water kefir. Therefore, this research aims to establish the optimal fermentation time for green coconut water kefir by assessing the physicochemical and sensory characteristics.

\section{Materials and Methods}

\section{$2.1 \quad$ Materials}

Five liters of commercially available coconut water was obtained at a Mulawarman Street store in Semarang, Central Java. Kefir grains were obtained from the beadsnik online shop located in Denpasar. Selenium, sulfuric acid, 4 $\% \mathrm{H}_{3} \mathrm{BO}_{3}$, Methyl Red (MR) and Methyl Blue (MB), Aquadest, $45 \% \mathrm{NaOH}, 0.1 \mathrm{~N} \mathrm{HCl}, 91 \%$
$\mathrm{H}_{2} \mathrm{SO}_{4}$, and amyl alcohol were used. Porcelain dishes, an oven (Memmert, Germany), Kjeldahl flasks (Pyrex, Japan) were also used.

\subsection{Kefir preparation from green coconut water}

The method used to produce green coconut water kefir was adapted from Lestari, Bintoro and Rizqiati (2018). The green coconut water was pasteurized for 30 seconds at $60{ }^{\circ} \mathrm{C}$, poured into jars and then cooled to $28{ }^{\circ} \mathrm{C}$. Kefir grains were added to the jars at $5 \%(\mathrm{w} / \mathrm{v})$ to begin the fermentation process. The kefir samples were treated with different fermentation times, which were 12 hours (T1), 24 hours (T2), 36 hours (T3) and 48 hours (T4). The coconut kefir was then filtered to separate the grains from the coconut water before the specified testing.

\subsection{Physicochemical properties}

\section{pH analysis}

The sample $\mathrm{pH}$ was measured using a $\mathrm{pH}$ meter (AOAC, 2013). The $\mathrm{pH}$ meter was calibrated with standard buffers ( $\mathrm{pH} 4.0$ and $\mathrm{pH} 7.0)$ just prior to use.

\section{Viscosity analysis}

The Ostwald viscometer was calibrated with deionized water. The mass of the pycnometer was weighed with an analytical balance, then again containing $10 \mathrm{~mL}$ of water and finally containing $10 \mathrm{~mL}$ of each sample. The time taken for each sample to drain by gravity between two etched marks of the Ostwald viscometer was measured. The viscosity of each sample was calculated according to the equation below (Fathima, Devi, Rekha \& Dhathathreyan, 2009):

$$
\eta_{s}=\eta_{w} \cdot \frac{t_{s}}{t_{w}} \cdot \frac{m_{p+s}-m_{p}}{m_{p+w}-m_{p}}
$$

$\mathbf{m}_{p}$ : Mass of pycnometer (g)

$\mathbf{m}_{p+s}$ : mass of pycnometer + filled volume of the sample $(\mathrm{g})$ 
$\mathbf{m}_{p+w}$ : mass of pycnometer + filled volume of water $(g)$

$\eta_{w}:$ water viscosity $(\mathrm{cP})$

$\eta_{s}:$ sample viscosity $(\mathrm{cP})$

$\mathbf{t}_{s}$ : drain time for sample $(\mathrm{s})$

$\mathbf{t}_{w}:$ drain time for water $(\mathrm{s})$

\section{Alcohol content}

The alcohol content was measured by distillation and a pycnometer (AOAC, 2013). The samples $(50 \mathrm{~mL})$ were placed in a Kjeldahl flask and 100 $\mathrm{mL}$ aquadest was then added. The distillation process occurred at $80{ }^{\circ} \mathrm{C}$ and the distillate was collected in an Erlenmeyer flask. Fifty $\mathrm{mL}$ of the distillate was transferred to a pycnometer. Excessive distillate was removed from the top of the capillary tube of the pycnometer. The distillatefilled pycnometer was then weighed. The same procedure was repeated for aquadest. The density of alcohol was calculated using the formula below:

$$
\rho=\frac{m_{p+d}-m_{p}}{m_{p+a}-m_{p}}
$$

$\rho$; Alcohol density $\left(\mathrm{g} / \mathrm{cm}^{3}\right)$

$\mathbf{m}_{p}$ : Mass of pycnometer (g)

$\mathbf{m}_{p+d}$ : mass of pycnometer + filled volume of the distillate $(\mathrm{g})$

$\mathbf{m}_{p+a}$ : mass of pycnometer + filled volume of aquadest $(\mathrm{g})$

The alcohol content was then obtained using the conversion table for alcohol.

\section{Total Dissolved Solids (TDS)}

Total Dissolved Solid (TDS) was measured by a hand-held refractometer (AOAC, 1995). Three drops of aquadest were added to the prism of the refractometer and then wiped off with tissue paper. Three drops of a sample were then added to the cleaned prism, and the lid shut properly. The scale was read at a bright room condition. It showed the percentage of Total Dissolved Solids according to the International Sugar Scale of 1936 in ${ }^{\circ}$ Brix unit. The prism of the refractometer was rinsed off again with tissue paper, before the next sample was measured.

\section{Water content}

Water content was measured by oven-drying. Empty porcelain dishes were dried in the oven at $105{ }^{\circ} \mathrm{C}$ for 4 hours, and then weighed using an analytical balance. Two grams of each sample was weighed out onto each dish, which were placed in the oven and dried at $105{ }^{\circ} \mathrm{C}$ for 4 hours. The dishes were then transferred, with partially covered lids, to the desiccator to cool down. The dishes and their dried samples were reweighed. The water content was calculated using the following formula based on AOAC (2005):

$$
\text { Water content }(\%)=\frac{B-(C-A)}{B} \times 100
$$

A : container's weight $(\mathrm{g})$

B : sample's initial weight $(\mathrm{g})$

C : container's and sample's weight after drying (g)

\section{Fat content}

Fat content was measured using the Gerber method (AOAC, 2002). A butyrometer was filled with $10 \mathrm{~mL}$ of sulfuric acid. Eleven $\mathrm{mL}$ of a sample and $1 \mathrm{~mL}$ of amyl alcohol were placed into the butyrometer. The tube was sealed with a rubber stopper and shaken until the sample was dissolved. The solution was then centrifuged for 15 minutes at $1200 \mathrm{rpm}$ and transferred from the butyrometer into a water bath at $60-63{ }^{\circ} \mathrm{C}$. The

\begin{tabular}{l|l|l|l} 
IJFS | October 2020 | Volume 9 & pages 346-359
\end{tabular} 
solution was immersed, leaving only the small bulb exposed. The fat column was equilibrated for 5 minutes or longer. The scale on the tube of the butyrometer was read to indicate the fat content of the sample.

\section{Protein content}

The protein content of a sample was determined based on the total nitrogen content using the Kjeldahl method. A half gram of sample was weighed and placed into the Kjeldahl flask. A half $\mathrm{mL}$ of selenium and $10 \mathrm{~mL}$ of sulfuric acid were then added to the flask. The resulting solution was digested until a clear-green color was achieved. The digested sample was then distilled. The trap which contains $5 \mathrm{~mL} 4 \% \mathrm{H}_{3} \mathrm{BO}_{4}$, two drops of MR and two drops of MB was placed below the distiller. The sample along with 100 $\mathrm{mL}$ aquadest and $40 \mathrm{ml} 45 \% \mathrm{NaOH}$ were added sequentially into the distillation flask. The stove was switched on and the distillation process was allowed to proceed until the trap changed its color from purple to green. Forty $\mathrm{mL}$ of distillate was obtained. For the blank control, the same procedure was repeated using $200 \mathrm{~mL}$ of aquadest. The distillate was titrated using $0.1 \mathrm{~N}$ $\mathrm{HCl}$ until the color turned to purple. The protein content was calculated using the following formula based on AOAC (2000):

$$
\operatorname{Protein}(\%)=\frac{(\text { titrant }- \text { blank }) \cdot N H C L \cdot 14.008 \cdot 6.25}{\text { Mass of the samples } \cdot 1000} \cdot 100 \%
$$

\subsection{Sensory evaluation test}

Sensory quality was evaluated by the rank test (Lawless \& Heymann, 1999). Twenty-five semitrained panelists (fifteen women and ten men) were used in this study. The age of the panelists were between 22 and 25 years. Panelists were given questionnaires containing name, test date, the names of the test samples and instructions. The sensory attributes assessed in this test were the level of sourness, sour aroma, soda sensation, turbidity and viscosity. Panelists evaluated five samples and ranked each attribute on a 1-4 scale. They were also instructed to cleanse their pal- ate with mineral water between evaluating each sample.

\subsection{Statistical analysis}

The parameters of $\mathrm{pH}$, viscosity, Total Dissolved Solids, alcohol content, protein content, fat content and water content were analysed statistically by Analysis of Variance (ANOVA) using SPSS V22.0. Duncan's multiple range test was then used to determine significant differences amongst the results. Non-parametric data arising from sensory evaluation was analysed by the Kruskal-Wallis test. The significant results obtained by sensory evaluation were investigated using the Mann Whitney u-test to determine significant differences from each treatment.

\section{Results and Discussion}

\subsection{Physicochemical properties}

\section{pH analysis}

Acidity level, denoted by $\mathrm{pH}$, is commonly used to determine the quality of fermented products as it influences the texture and flavour of the product. As shown in Table 1, pH was affected by the fermentation time. There was a significant difference in the fermentation duration of 12 hours, while in other treatments the difference was not significant. The pH after 12 hours of fermentation time was 4.6; and was 3.4 after 24 hours, 3.6 after 36 hours, and 3.68 after 48 hours. Generally, the $\mathrm{pH}$ of water kefir ranges between 3.5 and 4 (Randazzo et al., 2016).

The decrease in $\mathrm{pH}$ that occurred in kefir green coconut water after 24 hours of fermentation was due to the growth of bacteria that will convert sugar into lactic acid and acetic acid, thereby decreasing the $\mathrm{pH}$ of the product. This was consistent with the findings of Delgado-Fernandez, Corzo, Olano, Hernandez-Hernandez and Javier Moreno (2019) which stated that the longer the fermentation time, the more active the bacteria and the greater the accumulation of organic acids resulting in increased sourness. The presence of too many free hydrogen ions $\left(\mathrm{H}^{+}\right)$may affect the survival of the bacteria after 36 and 48 hours of 
fermentation. A longer fermentation time will lead to the death of microorganisms present in kefir due to increasing alcohol levels and decreasing nutrients available for growth (Laureys \& De Vuyst, 2014). This result showed that $\mathrm{pH}$ can be used as a reference to determine the optimal time to end the fermentation process.

\section{Viscosity analysis}

As shown in Table 1, the viscosity of green coconut water kefir throughout the fermentation period ranged from 0.08 to $0.1 \mathrm{cP}$ and was not affected by fermentation time. According to Zannini, Waters, Coffey and Arendt (2016), the viscosity is low if it is less than $2 \mathrm{cP}$ for a $5 \% \mathrm{w} / \mathrm{w}$ solution in water. Viscosity in a fermented beverage was affected by the nutrient content of the raw material and the production process.

Green coconut water contains about $0.72 \mathrm{~g} / 100$ $\mathrm{g}$ of protein which is a low amount (Yong et al., 2009). Protein content in raw materials is one of the most important factors in determining kefir viscosity. A low protein content in raw materials results in a low viscosity of water kefir since there is insufficient energy for the growth of microbes (Dimitreli, Petridis, Akakiadou \& Chrysalidou, 2014). Sabokbar, Moosavi-Nasab and Khodaiyan (2015) also reported that the viscosity values of kefir are related to exopolysaccharide (EPS) or kefiran production by the kefir grain during the fermentation. Therefore, sufficient nutrient content and optimal fermentation conditions are needed to obtain the desired viscosity.

Gul, Atalar, Mortas and Dervisoglu (2018) also observed that kefir viscosity increases with higher fat content as the interaction of fat globule membranes in the protein network improves water holding capacity (WHC) and results in the formation of a more stable gel. Green coconut water kefir contains $0.33 \mathrm{~g} / 100 \mathrm{~mL}$ of fat which a low amount (Prades, Dornier, Diop \& Pain, 2012). Other factors that may affect the viscosity of kefir are the state of the protein in the main ingredients, total solids and the ability of microbes to produce acid during fermentation (Yoo, Seong \& Yoon, 2013).

\section{Total Dissolved Solids (TDS)}

In the present study, there were significant differences in TDS across different fermentation times $(\mathrm{P}<0.05)$. Significant differences were found in the fermentation periods of 12, 24 and 48 hours; but 36 hours was not significantly different from 24 hours of fermentation. The TDS values of the treatments were $3.8^{\circ} \mathrm{Brix}, 2.16^{\circ} \mathrm{Brix}, 2.04{ }^{\circ} \mathrm{Brix}$ and $1.04^{\circ}$ Brix, respectively.

The TDS values reduced with increasing fermentation time. TDS indicates the amount of sugar dissolved in coconut water which mostly consists of glucose, fructose and sucrose. According to Yong et al. (2009), the amount of TDS in green coconut water is $21.68 \mathrm{mg} / \mathrm{mL}$, consisting of 9.18 $\mathrm{mg} / \mathrm{mL}$ sucrose, $7.25 \mathrm{mg} / \mathrm{mL}$ glucose and 5.25 $\mathrm{mg} / \mathrm{mL}$ fructose. The TDS values of $\mathrm{T} 1$ to T4 decreased due to the fermentation process. Yeast in kefir grain can hydrolyze sucrose into monosaccharides, namely glucose and fructose through the action of invertase enzymes. Glucose that is produced from this activity is subsequently transformed into organic acids. This is consistent with Gulitz, Stadie, Wenning, Ehrmann and Vogel (2011) who stated that generally all species of yeast contained in water kefir along with lactic acid bacteria (LAB) produce organic acids from glucose. The accumulation of acid as a product of $\mathrm{LAB}$ activity can also trigger a decrease in sugar content, as shown by the results of T4. The process of breaking down sugar by microbes from water kefir grain continuously reduces the availability of sugar and increases the acids. Jeong, Lee, Jung, Choi and Jeon (2013) reported that a decrease in nutrient availability and the accumulation of organic acids produced by LAB occurs with the increasing fermentation duration. Furthermore, these nutrients will deplete and cause an increase in alcohol accumulation which results in microbes entering the death phase.

\section{Alcohol content}

The observed results showed that fermentation time significantly affected the alcohol content of green coconut water kefir, where alcohol content increased with longer fermentation periods. The average alcohol content produced in samples fermented for 12, 24, 36 and 48 hours 
Physicochemical and sensory characteristics of green coconut water kefir $\mid 351$

Table 1: Physical Characteristics of Green Coconut Water Kefir

\begin{tabular}{lllll}
\hline \multirow{2}{*}{ Parameters } & \multicolumn{4}{c}{ Treatments (hours) } \\
\cline { 2 - 5 } & 12 & 24 & 36 & 48 \\
\hline $\mathrm{pH}$ & $4.6 \pm 0.27^{a}$ & $3.4 \pm 0.07^{b}$ & $3.6 \pm 0.27^{b}$ & $3.68 \pm 0.07^{b}$ \\
Viscosity $(\mathrm{cP})$ & $0.09 \pm 0.03^{\text {ns }}$ & $0.1 \pm 0.01^{\text {ns }}$ & $0.1 \pm 0.04^{\text {ns }}$ & $0.08 \pm 0.01^{\text {ns }}$ \\
\hline
\end{tabular}

Data shown as the mean of repetitions \pm standard deviation (SD). Different superscript letters on the same horizontal line show significant differences $(\mathrm{p}<0.05)$.

Table 2: Chemical Characteristics of Green Coconut Water Kefir

\begin{tabular}{lllll}
\hline Parameters & \multicolumn{3}{c}{ Treatments (hours) } \\
\cline { 2 - 4 } & 12 & 24 & 36 \\
\hline Total Dissolved Solids $\left({ }^{o}\right.$ Brix) & $3.8 \pm 0.14^{a}$ & $2.04 \pm 0.09^{b}$ & $2.16 \pm 0.48^{b}$ & $1.04 \pm 0.09^{c}$ \\
Alcohol content (\%) & $1.16 \pm 0.16^{a}$ & $1.96 \pm 0.18^{b}$ & $2.80 \pm 0.93^{c}$ & $4.14 \pm 0.87^{d}$ \\
Water Content (\%) & $97.14 \pm 0.09^{a}$ & $97.19 \pm 0.07^{a}$ & $97.1 \pm 0.06^{a}$ & $97.35 \pm 0.12^{b}$ \\
Protein Content (\%) & $6.04 \pm 0.94^{a}$ & $5.46 \pm 0.39^{a}$ & $5.05 \pm 0.92^{a b}$ & $4.05 \pm 0.84^{b}$ \\
Fat Content (\%) & $1.7 \pm 0.38^{n s}$ & $1.95 \pm 0.31^{n s}$ & $1.75 \pm 0.27^{n s}$ & $1.67 \pm 0.39^{n s}$ \\
\hline
\end{tabular}

Data shown as the mean of repetitions \pm standard deviation (SD). Different superscript letters on the same horizontal line show significant differences $(\mathrm{p}<0.05)$.

Table 3: Sensory Test of Green Coconut Water Kefir

\begin{tabular}{lllll}
\hline Sensory Attributes & \multicolumn{4}{c}{ Treatments (hours) } \\
\cline { 2 - 5 } & 12 & 24 & 36 & 48 \\
\hline Level of Sourness & $3.52 \pm 0.96^{a}$ & $2.28 \pm 0.68^{b}$ & $1.60 \pm 1.04^{c}$ & $2.60 \pm 0.87^{b}$ \\
Soda Sensation & $2.40 \pm 1.50^{n s}$ & $2.40 \pm 0.76^{n s}$ & $2.28 \pm 0.94^{n s}$ & $2.92 \pm 1.12^{n s}$ \\
Sour Aroma & $3.52 \pm 1.00^{a}$ & $2.56 \pm 0.87^{b}$ & $2.24 \pm 0.72^{b}$ & $1.68 \pm 1.03^{c}$ \\
Viscosity & $2.52 \pm 1.26^{n s}$ & $2.76 \pm 1.05^{n s}$ & $2.00 \pm 1.12^{n s}$ & $2.76 \pm 0.97^{n s}$ \\
Turbidity & $3.12 \pm 1.30^{a}$ & $2.16 \pm 1.07^{b}$ & $2.48 \pm 0.92^{b}$ & $2.24 \pm 0.97^{b}$ \\
\hline
\end{tabular}

Data shown as the mean of repetitions \pm standard deviation (SD). Different superscript letters on the same horizontal line show significant differences $(\mathrm{p}<0.05)$. Sensory test scores from 1 to 4 represent: very high, high, low, very low 
were $1.16 \%, 1.96 \%, 2.80 \%$ and $4.14 \%$, respectively. Longer fermentation periods were associated with the higher activity of yeast and alcohol-producing microbes. The microbes that are primarily responsible for producing alcohol in kefir grain is yeast (Saccharomyces cerevisiae) (de Melo Pereira, Ramos, Galvao, Souza Dias \& Schwan, 2010). Some Lactobacillus strains also have the ability to produce alcohol because they have alcohol-dehydrogenase that can convert substrates into ethanol (Magalhães-Guedes, Pereira, Campos, Dragone \& Schwan, 2011).

A study on pomegranate and orange juice kefir by Kazakos et al. (2016) found that the alcohol level was below $1 \%$. Similar results were also found in brown sugar (Magalhães-Guedes, Pereira, Dias \& Schwan, 2010) and cow's milk kefir (Zajsek \& Gorsek, 2010). In general, the alcohol content of kefir usually ranges from 0.5 to $2 \%$ depending on the substrate used (Setyawardani, Rahardjo, Sulistyowati \& Wasito, 2014). The higher alcohol content observed in green coconut was possibly due to the higher sugar content of $21 \mathrm{mg} / \mathrm{mL}$, consisting of sucrose, glucose and fructose, in green coconut water (Yong et al., 2009). These sugar matrices stimulate the metabolism of kefir yeast, resulting in increased concentrations of ethanol, glycerol and esters in the final product. These metabolites provide the distinct sensory characteristics of kefir such as refreshing flavor, fruity aroma and texture (Fiorda et al., 2017). In conclusion, fermentation for 12 hours gave the best alcohol contentamong the treatments.

\section{Water content}

It was found that the average water contents of green coconut kefir, with a fermentation time of $12,24,36$ and 48 hours were $97.14 \%, 97.19 \%$, $97.1 \%$ and $97.35 \%$, respectively. Fermentation time had a significant effect on water content but there was no significant difference between green coconut water kefir of treatments $\mathrm{T} 1, \mathrm{~T} 2$ and T3. Magalhães-Guedes et al. (2010) and RochaGomes et al. (2018) also found similar results in Brazilian sugary water kefir and brown sugar water kefir within a range of 95-98\%. The high water content of kefir in the current study was also caused by the largest component of the medium which consists of 95\% water (Yong et al., 2009), hence the name water kefir.

The water content tends to increase with longer fermentation period. Currently, research on physicochemical properties of water kefir, especially water content, is still limited. However, the increase of water content that occurred after 48 hours of fermentation was allegedly due to the decreasing ability of kefir grains to retain moisture. Kefir grain is a matrix of exopolysaccharide (EPS) which is capable of binding with water in aqueous solution (Wang, Zhao, Tian, Yang \& Yang, 2015). The reduction of EPS or kefiran might also give rise to this finding, where more moisture is available in the product. As reported by Kok-Tas, Seydim, Ozer and Guzel-Seydim (2013), enzymatic degradation of EPS occurs during fermentation and the storage period of kefir, and leads to a decrease in EPS content.

\section{Protein content}

Based on the results, fermentation time affected the protein content in green coconut water kefir. Protein levels significantly decreased from T1 to T4, although T2 was not significantly different to T3. This is consistent with the results of Mechmeche, Kachouri, Ksontini, Setti and Hamdi (2018) who found that kefir can reduce protein levels and increase antioxidant activity during fermentation through the production of bioactive peptides. Protein content of samples throughout the fermentation period ranged between $4.05 \%$ and $6.04 \%$. These results were higher than the protein content of Brazilian sugary water kefir fermented for 24 hours which was $0.4 \%$ (Magalhães-Guedes et al., 2010) and brown sugar water kefir which was $0.27 \%$ after 48 hours fermentation (Rocha-Gomes et al., 2018). The protein content of a fermented product usually increases with fermentation time due to the increase of microbial biomass and secretion of protein molecules (Magalhães-Guedes et al., 2011). A different result was obtained in this study where the protein content decreased with increasing fermentation time. This is supposedly due to an inadequate supply of nutrients after 24 hours or a medium acidity level that is incompatible with the microbes' survival and leads to their death. The type and amount of protein con- 
tained in the main ingredient may also affect the quality of kefir where the protein may coagulate during fermentation due to lactic acid accumulation and produce different functional peptides (Shi, Chen, Li, Huang \& He, 2018). Overall, T1 (with 12 hours of fermentation time) had the best result among the treatments.

\section{Fat content}

As shown in Table 2, there was no significant differences in the fat content of water kefir with different fermentation times $(\mathrm{P}>0.05)$. The fat content produced at $12,24,36$ and 48 hours of fermentation were $1.7 \%, 1.95 \%, 1.75 \%$ and 1.67 $\%$, respectively. These findings suggest the duration of fermentation did not affect fat content of water kefir. However, there was a decrease if fat content from 24 hours to 48 hours of fermentation. This is possibly due to the lipases produced by the kefir grain (Gonzalez-Sanchez, Azaola, Gutierrez-Lopez \& Hernandez-Sanchez, 2010). Another explanation is the production of invertase enzyme by microbes in kefir grain, which hydrolyze sucrose into glucose and fructose that are subsequently transformed into organic acids by yeast and LAB (Fiorda et al., 2017).

Fat is a minor component of green coconut water kefir, with a fat content lower than that in milk kefir $(2.34 \%)$ fermented for 24 hours (MagalhãesGuedes et al., 2011). This is in accordance with the observations of Prades et al. (2012) who reported the fat content of coconut water to be around $0.33 \mathrm{~g} / 100 \mathrm{~mL}$. A low fat content makes water kefir a good alternative for those with cholesterol issues who seek a low calories beverage with similar health benefits as milk kefir. Fat content affects the texture of kefir. A higher fat content will increase water holding capacity (WHC) of the product and cause a firmer consistency and higher viscosity (Gul et al., 2018).

\subsection{Sensory evaluation}

Sensory test results for green coconut water kefir included level of sourness, soda sensation, sour aroma, viscosity and turbidity (Table 3).

\section{Level of sourness of green coconut water kefir}

Sensory test results on green coconut water kefir showed that differences in fermentation time had significant effects $(\mathrm{P}<0.05)$ on the level of sourness. As shown in Table 3, panelists could distinguish differences in the level of sourness of treatments. However, the level of sourness for the T2 (24 hours) and T4 (48 hours) treatments tended to be indistinguishable. The T3 (36 hours) treatment was known to have the highest sourness caused by the fermentation process. Fermentation by kefir grain produces lactic acid as the main metabolite. Acetic acid, glycerol and mannitol were also produced in low concentrations (Laureys \& De Vuyst, 2014). The level of sourness should increase with increasing fermentation time. However, this did not occur in $\mathrm{T} 4$ where kefir grain cells entered the death phase due to an excessive fermentation process. Longer fermentation times can cause the accumulation of metabolites (lactic acid and carbon dioxide) which can then inhibit the growth of cells and result in a non-optimal fermentation process (Yuliana, 2012).

\section{Soda sensation of green coconut water kefir}

The soda sensation is the impression of numbing, burning or biting when consuming food products containing carbon dioxide (Kappes, Schmidt \& Lee, 2007). Sensory tests on green coconut water kefir showed that the panelists could not distinguish the soda sensation between different treatments. The bursting of carbon dioxide bubbles is a metabolite result of sugar conversion by microorganisms (Wu et al., 2010). A limited sugar content in green coconut water could only produce a small amount of carbon dioxide through yeast fermentation thus the inability to distinguish between treatments.

\section{Sour Aroma of Green Coconut Water Kefir}

The differences in fermentation time had significant effects $(\mathrm{P}<0.05)$ on the sour aroma of green coconut water kefir. The intensity of

IJFS | October 2020 | Volume $9 \mid$ pages 346-359 


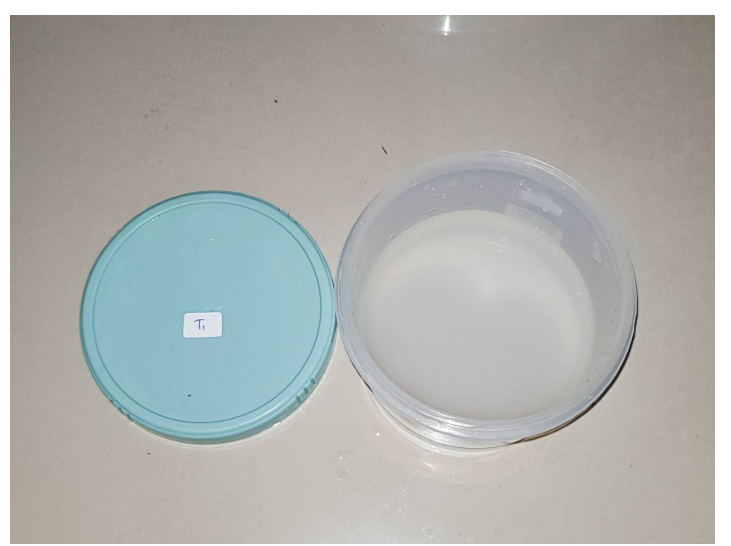

(a) 12 hours

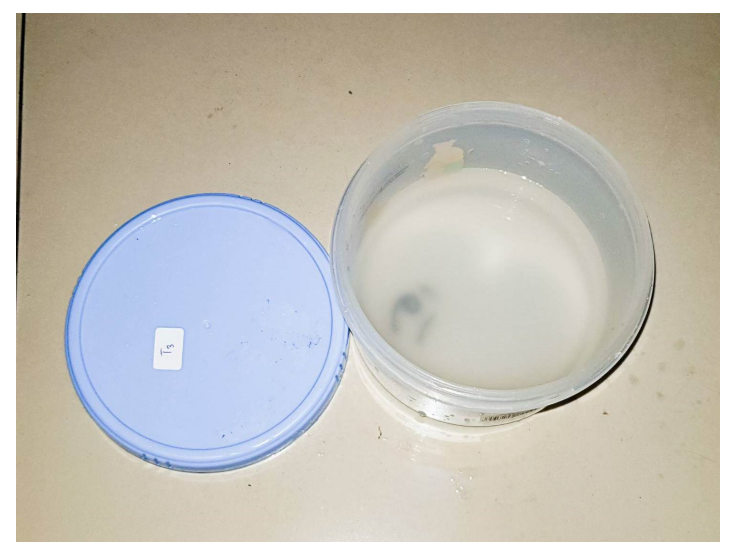

(c) 36 hours

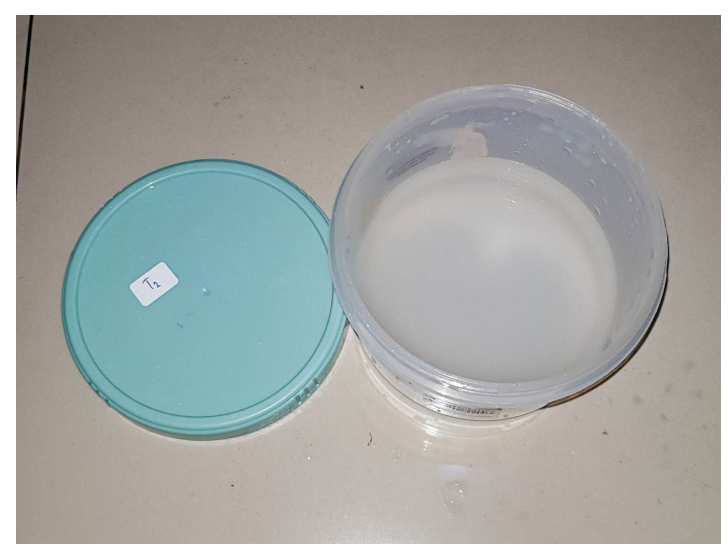

(b) 24 hours

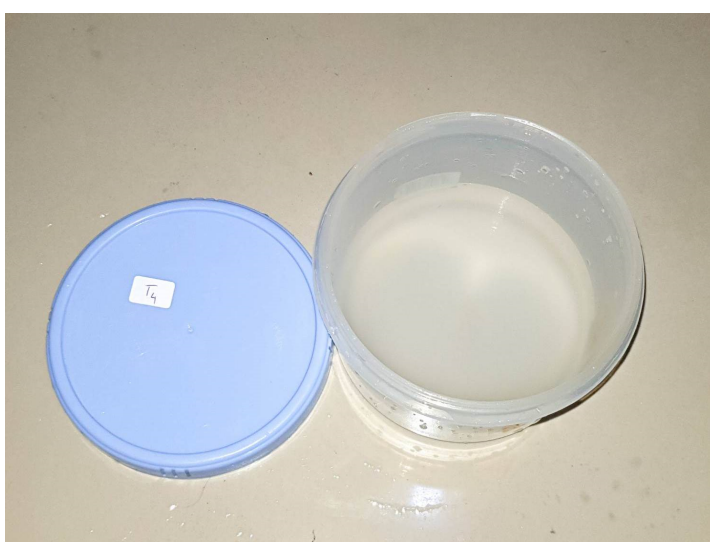

(d) 48 hours

Figure 1: Green coconut water kefir fermentation

sour aroma increased with fermentation time. This is shown in Table 3 . The average value of sour aroma was the lowest in T4 (48 hours). Sour aroma increased due to the presence of volatile compounds during the fermentation process. Kefir grains produced aroma-forming compounds due to the presence of volatile compounds such as acetaldehyde, acetone, ethyl acetate, 2-butanone, diacetyl and ethanol (Cheng, 2010). The longer the fermentation time, the more volatile compounds that are produced, increasing the intensity of the sour aroma (Beshkova, Simova, Frengova, Simov \& Dimitrov, 2003).

\section{Viscosity of Green Coconut Water Kefir}

Sensory tests showed that panelists could not distinguish the viscosity of the green coconut water kefir across the different treatments. This is also in accordance with the quantitative analysis of viscosity that showed there were no significant differences in viscosity with fermentation time. The viscosity of a solution tends to increase with the addition of ingredients such as sweeteners or fibers (Mattes \& Rothacker, 2001). However, there was no addition of those ingredients in the manufacturing process of green coconut water kefir, thus viscosity was not affected. Furthermore, as green coconut water contains only a low amount of protein the resulting viscosity may 
not change significantly as fermentation time increases. In a fermented beverage, protein denaturation could lead to texture thickening of a finished product (Novelina, Sayuti \& Rahmadani, 2013).

\section{Turbidity of Green Coconut Water Kefir}

Sensory tests of green coconut water kefir showed that the differences in fermentation time had a significant effect $(\mathrm{P}<0.05)$ on turbidity. As shown in Table 3, panelists were able to distinguish the turbidity of green coconut water kefir between T1 (12 hours) and the other treatments. However, T2 (24 hours), T3 (36 hours) and T4 (48 hours) tended to be indistinguishable. As shown in Figure 1(a), T1 (12 hours) produced a clearer solution than other treatments. While T2 (24 hours), T3 (36 hours) and T4 (48 hours), as presented in Figures 1(b)-1(d), were apparently similar. Panelists considered that T1 produced a lower turbidity intensity than the other treatments due to a shorter fermentation time. Under a short fermentation time, cells in the kefir grain were still in the adaptation phase, whilst in the other treatments the cells were already in the growth phase and thus increasing in number. This is in accordance with Parhusip and Kusuma (2003) who stated that the greater the number of microbes, the higher the turbidity of solutions.

\section{Conclusions}

This study showed that longer fermentation times were associated with less favorable physical and chemical characteristics in green coconut water kefir. The ideal fermentation time for producing green coconut water kefir was 12 hours, resulting in a $\mathrm{pH}$ of 4.6 , viscosity of $0.09 \mathrm{cP}$, TDS of $3.8^{\circ}$ Brix, alcohol content of $1.16 \%$, water content of $97.14 \%$, protein content of $6.64 \%$, fat content of $1.17 \%$ and a lower level of sourness that was considered more acceptable by the panelists.

\section{Acknowledgements}

The authors would like to thank to Anggun Dwi Puspitoasih, Lita Lusiana Surja, Savira Oktavina Cahyani, and Yolanda Yunivia for their assistance in carrying out this research.

\section{References}

AOAC. (1995). Official methods of analysis of the association of the official analytical chemists. volume ii. 16th edition. 5th revision. usa: Aoac international. (edited by p. cunnif).

AOAC. (2000). Official methods of analysis of the of association of the official analytical chemists. 17th edition. usa: Aoac international. (edited by william horwtiz).

AOAC. (2002). Official methods of analysis. appendix g: Guidelines for collaborative study procedures to validate characteristics of a method of analysis. usa: Aoac international.

AOAC. (2005). Official methods of analysis of the association of the official analytical chemists. washington dc: Benjamin franklin station.

AOAC. (2013). Official method of analysis of the association of the official analytical chemistry. washington dc: Aoac international.

Beshkova, D., Simova, E., Frengova, G., Simov, Z. \& Dimitrov, Z. (2003). Production of volatile aroma compounds by kefir starter cultures. International Dairy Journal, 13(7), 529-535. doi:10 . 1016/ S0958-6946(03)00058-X

Cappelletti, M., Ferrentino, G., Endrizzi, I., Aprea, E., Betta, E., Corollaro, M., ... Spilimbergo, S. (2015). High pressure carbon dioxide pasteurization of coconut water: A sport drink with high nutritional and sensory quality. Journal of Food Engineering, 145, 73-81. doi:10.1016/j.jfoodeng. 2014.08.012

Chang, C.-L. \& Wu, R.-T. (2011). Quantification of $(+)$-catechin and ()-epicatechin in coconut water by lc-ms. Food Chemistry, 126(2), 710-717. doi:10.1016/j.foodchem. 2010.11 .034 
Cheng, H. (2010). Volatile flavor compounds in yogurt: A review. Critical Reviews in Food Science and Nutrition, 50(10), 938-950. doi:10.1080/10408390903044081

Chidambaram, S., Singaraja, C., Prasanna, M. V., Ganesan, M. \& Sundararajan, M. (2013). Chemistry of tender coconut water from the cuddalore coastal region in tamil nadu, india. Natural Resources Research, 22(2), 91-101.

de Melo Pereira, G. V., Ramos, C. L., Galvao, C., Souza Dias, E. \& Schwan, R. F. (2010). Use of specific pcr primers to identify three important industrial species of Saccharomyces genus: Saccharomyces cerevisiae, Saccharomyces bayanus and Saccharomyces pastorianus. Letters in Applied Microbiology, 51(2), 131-137. doi:10.1111/j.1472-765X. 2010.02868.x

Delgado-Fernandez, P., Corzo, N., Olano, A., Hernandez-Hernandez, O. \& Javier Moreno, F. (2019). Effect of selected prebiotics on the growth of lactic acid bacteria and physicochemical properties of yoghurts. International Dairy Journal, 89, 77-85. doi:10.1016/j.idairyj.2018.09.003

Dimitreli, G., Petridis, D., Akakiadou, P. \& Chrysalidou, S. (2014). Effect of protein supplementation, fat globule size and storage time on the rheological and sensory properties of buffalo milk stirred yogurt. Journal of food research, 3(5), 31. doi:10. 5539/jfr.v3n5p31

Evans, P. \& Halliwell, B. (2001). Micronutrients: Oxidant/antioxidant status. British Journal of Nutrition, 85(S2), S67-S74. doi:10.1049/BJN2000296

Fathima, N. N., Devi, R. S., Rekha, K. B. \& Dhathathreyan, A. (2009). Collagencurcumin interaction-a physico-chemical study. Journal of Chemical Sciences, $121(4), 509-514$.

Fiorda, F. A., de Melo Pereira, G. V., ThomazSoccol, V., Rakshit, S. K., Binder Pagnoncelli, M. G., de Souza Vandenberghe, L. P. \& Soccol, C. R. (2017). Microbiological, biochemical, and functional aspects of sugary kefir fermentation-a review. Food $M i$ crobiology, 66, 86-95. doi:10.1016/j.fm . 2017.04.004
Flávera, C. P., Juliano, D. D. L., Juliana, I., Vanete, T.-S., Satinder, K. B. \& Carlos, R. S. (2015). Development and evaluation of a fermented coconut water beverage with potential health benefits. Journal of Functional Foods, 12, 489-497. doi:10.1016/j.jff. 2014.12.020

Franco, A., Yamamoto, L., Tadini, C. \& Gut, J. (2015). Dielectric properties of green coconut water relevant to microwave processing: Effect of temperature and field frequency. Journal of Food Engineering, 155. doi:10.1016/j.jfoodeng.2015.01.011

Ge, L., Yong, J., Goh, N., Chia, L., Tan, S. \& Ong, E. (2006). Identification of kinetin and kinetin riboside in coconut ( $\mathrm{Co}$ cos Nucifer 1.) water using a combined approach of liquid chromatography-tandem mass spectrometry, high performance liquid chromatography and capillary electrophoresis. Journal of chromatography. B, Analytical technologies in the biomedical and life sciences, 829, 26-34. doi:10.1016/ j.jchromb.2005.09.026

Gonzalez-Sanchez, F., Azaola, A., GutierrezLopez, G. F. \& Hernandez-Sanchez, H. (2010). Viability of microencapsulated bifidobacterium animalis ssp lactis bb12 in kefir during refrigerated storage. International Journal of Dairy Technology, 63(3), 431-436. doi:10.1111/j.1471-0307.2010. 00604.x

Gul, O., Atalar, I., Mortas, M. \& Dervisoglu, M. (2018). Rheological, textural, colour and sensorial properties of kefir produced with buffalo milk using kefir grains and starter culture: A comparison with cows' milk kefir. International Journal of Dairy Technology, 71 (1, SI), 73-80. doi:10.1111/14710307.12503

Gulitz, A., Stadie, J., Wenning, M., Ehrmann, M. A. \& Vogel, R. F. (2011). The microbial diversity of water kefir. International Journal of Food Microbiology, 151 (3), 284288. doi:10.1016/j.ijfoodmicro.2011.09.016

Ismaiel, A. A., Ghaly, M. F. \& El-Naggar, A. K. (2011). Some physicochemical analyses of kefir produced under different fermentation conditions. Journal of Scientific $\&$ Industrial Research, 70(5), 365-372. 
Physicochemical and sensory characteristics of green coconut water kefir $\mid 357$

Jeong, S. H., Lee, S. H., Jung, J. Y., Choi, E. J. \& Jeon, C. O. (2013). Microbial succession and metabolite changes during longterm storage of kimchi. Journal of Food Science, 78(5), M763-M769. doi:10.1111/ $1750-3841.12095$

Kailaku, S., Syah, A., Risfaheri, R., Setiawan, B. \& Sulaeman, A. (2015). Carbohydrateelectrolyte characteristics of coconut water from different varieties and its potential as natural isotonic drink. International Journal on Advanced Science, Engineering and Information Technology, 5, 174. doi:10. 18517/ijaseit.5.3.515

Kappes, S. M., Schmidt, S. J. \& Lee, S. .-.-Y. (2007). Relationship between physical properties and sensory attributes of carbonated beverages. Journal of Food Science, 72(1), S1-S11. doi:10.1111/j.17503841.2006.00205.x

Kazakos, S., Mantzourani, I., Nouska, C., Alexopoulos, A., Bezirtzoglou, E., Bekatorou, A., ... Varzakas, T. (2016). Production of lowalcohol fruit beverages through fermentation of pomegranate and orange juices with kefir grains. Current Research in Nutrition and Food Science, 4 (1), 19-26. doi:10. 12944/CRNFSJ.4.1.04

Kok-Tas, T., Seydim, A. C., Ozer, B. \& GuzelSeydim, Z. B. (2013). Effects of different fermentation parameters on quality characteristics of kefir. Journal of Dairy Science, 96 (2), 780-789. doi:10.3168/jds.2012-5753

Laureys, D. \& De Vuyst, L. (2014). Microbial species diversity, community dynamics, and metabolite kinetics of water kefir fermentation. Applied and Environmental Microbiology, 80(8), 2564-2572. doi:10 . 1128/AEM.03978-13. eprint: https://aem. asm.org/content/80/8/2564.full.pdf

Lawless, H. T. \& Heymann, H. H. (1999). Sensory evaluation of food. Principles and practices. doi:10.1007/978-1-4419-7452-5_2

Lestari, M. W., Bintoro, V. P. \& Rizqiati, H. (2018). The effect of fermentation time to the level of sourness, viscosity, alcohol content, and hedonic characteristic on water kefir. Food Technology Journal, 2(1), 8-13. Retrieved from https://ejournal3.undip. ac.id/index.php/tekpangan/article/view/ 20750/0

Liu, J.-R. \& Lin, C.-W. (2000). Production of kefir from soymilk with or without added glucose, lactose, or sucrose. Journal of Food Science, 65(4), 716-719. doi:10.1111/j . 1365-2621.2000.tb16078.x

Magalhães-Guedes, K., Pereira, G., Campos, C., Dragone, G. \& Schwan, R. (2011). Brazilian kefir: Structure, microbial communities and chemical composition. Brazilian journal of microbiology : [publication of the Brazilian Society for Microbiology], 42, 693-702. doi:10.1590/S1517838220110002000034

Magalhães-Guedes, K., Pereira, G., Dias, D. \& Schwan, R. (2010). Microbial communities and chemical changes during fermentation of sugary brazilian kefir. World journal of microbiology \& biotechnology, 26, 1241-50. doi:10.1007/s11274-009-0294-x

Mandal, S. M., Dey, S., Mandal, M., Sarkar, S., Maria-Neto, S. \& Franco, O. L. (2009). Identification and structural insights of three novel antimicrobial peptides isolated from green coconut water. Peptides, 30(4), 633-637. doi:10.1016/j.peptides.2008.12. 001

Marsh, A. J., Hill, C., Ross, R. P. \& Cotter, P. D. (2014). Fermented beverages with healthpromoting potential: Past and future perspectives. Trends in Food Science \& Technology, 38(2), 113-124. doi:10.1016/j.tifs. 2014.05.002

Marsh, A. J., O'Sullivan, O., Hill, C., Ross, R. P. \& Cotter, P. D. (2013). Sequence-based analysis of the microbial composition of water kefir from multiple sources. Fems $M i$ crobiology Letters, 348(1), 79-85. doi:10. 1111/1574-6968.12248

Mattes, R. D. \& Rothacker, D. (2001). Beverage viscosity is inversely related to postprandial hunger in humans. Physiology $\&$ Behavior, 74 (4-5), 551-557. doi:10.1016/S00319384(01)00597-2

Mechmeche, M., Kachouri, F., Ksontini, H., Setti, K. \& Hamdi, M. (2018). Bioprocess development and preservation of functional food from tomato seed isolate fermented by kefir culture mixture. Journal of Food Sci-

\begin{tabular}{l|l|l|l} 
IJFS | October 2020 | Volume 9 & pages 346-359
\end{tabular} 
ence and Technology-mysore, 55(10), 39113921. doi:10.1007/s13197-018-3315-7

Novelina, N., Sayuti, K. \& Rahmadani, N. (2013). Characteristics of fermentation drink made from juice of winged bean sprouts (Psophocarpus tetragonolobus) and red sweet potato (Ipomoea batatas). International Journal on Advanced Science, Engineering and Information Technology, 3, 359. doi:10.18517/ijaseit.3.6.341

Pandin, D. S. (2015). Penanda dna untuk pemuliaan tanaman kelapa (Cocos nucifera l.) Perspektif, 9(1), 21-35. Retrieved from http : / / ejurnal. litbang. pertanian.go.id / index.php/psp/article/view/2721

Parhusip, A. \& Kusuma, I. P. (2003). Characteristic of noni (Morinda citrifolia linn) fruit juice produced by fermentation. Jurnal Teknologi dan Industri Pangan, 14 (2), 144.

Prades, A., Dornier, M., Diop, N. \& Pain, J.-P. (2012). Coconut water uses, composition and properties: A review. Fruits, 67(2), 87107. doi:10.1051/fruits/2012002

Randazzo, W., Corona, O., Guarcello, R., Francesca, N., Germana, M. A., Erten, H., .. Settanni, L. (2016). Development of new non-dairy beverages from mediterranean fruit juices fermented with water kefir microorganisms. Food Microbiology, 54, 40-51. doi:10.1016/j.fm.2015.10.018

Rocha-Gomes, A., Escobar, A., Soares, J. S., da Silva, A. A., Villela Dessimoni-Pinto, N. A. \& Riul, T. R. (2018). Chemical composition and hypocholesterolemic effect of milk kefir and water kefir in wistar rats. Revista De Nutricao-brazilian Journal of $\mathrm{Nu}$ trition, 31(2), 137-145. doi:10.1590/167898652018000200001

Sabokbar, N., Moosavi-Nasab, M. \& Khodaiyan, F. (2015). Preparation and characterization of an apple juice and whey based novel beverage fermented using kefir grains. Food Science and Biotechnology, 24(6), 20952104. doi:10.1007/s10068-015-0278-6

Santana, I. A., Ribeiro, E. P. \& Iguti, A. M. (2011). Evaluation of green coconut ( $\mathrm{Co}$ cos nucifera 1.) pulp for use as milk, fat and emulsifier replacer in ice cream. In G. Saravacos, P. Taoukis, M. Krokida, V. Karathanos, H. Lazarides, N. Stoforos, ... S. Yan- niotis (Eds.), 11th international congress on engineering and food (icef11) (Vol. 1, pp. 1447-1453). Procedia Food Science. 11th International Congress on Engineering and Food (ICEF), Athens, GREECE, MAY 22-26, 2011. doi:10.1016/j.profoo. 2011.09.214

Santos, J. L. A., Bispo, V. S., Filho, A. B. C., Pinto, I. F. D., Dantas, L. S., Vasconcelos, D. F., ... Matos, H. R. (2013). Evaluation of chemical constituents and antioxidant activity of coconut water (Cocus nucifera 1.) and caffeic acid in cell culture. Anais Da Academia Brasileira De Ciencias, 85(4), 1235-1246. doi:10.1590/000137652013105312

Setyawardani, T., Rahardjo, A., Sulistyowati, M. \& Wasito, S. (2014). Physiochemical and organoleptic features of goat milk kefir made of different kefir grain concentration on controlled fermentation. 16, 48-54.

Shi, X., Chen, H., Li, Y., Huang, J. \& He, Y. (2018). Effects of kefir grains on fermentation and bioactivity of goat milk. Acta Universitatis Cibiniensis. Series E: Food Technology, 22, 43-50. doi:10.2478/aucft-20180005

Tan, T.-C., Cheng, L.-H., Bhat, R., Rusul, G. \& Easa, A. M. (2014). Composition, physicochemical properties and thermal inactivation kinetics of polyphenol oxidase and peroxidase from coconut (Cocos nucifera) water obtained from immature, mature and overly-mature coconut. Food Chemistry, 142, 121-128. doi:10.1016/j . foodchem . 2013.07 .040

Wang, J., Zhao, X., Tian, Z., Yang, Y. \& Yang, Z. (2015). Characterization of an exopolysaccharide produced by Lactobacillus plantarum yw11 isolated from tibet kefir. Carbohydrate Polymers, 125, 16-25. doi:10. 1016/j.carbpol.2015.03.003

Wu, X., Staggenborg, S., Propheter, J. L., Rooney, W. L., Yu, J. \& Wang, D. (2010). Features of sweet sorghum juice and their performance in ethanol fermentation. Industrial Crops and Products, 31(1), 164170. doi:10.1016/j.indcrop.2009.10.006

Yong, J. W. H., Ge, L., Ng, Y. F. \& Tan, S. N. (2009). The chemical composition and bio- 
Physicochemical and sensory characteristics of green coconut water kefir $\mid 359$

logical properties of coconut (Cocos nucifera 1.) water. Molecules, $14(12), 5144-$ 5164. doi:10.3390/molecules14125144

Yoo, S.-H., Seong, K.-S. \& Yoon, S.-S. (2013). Physicochemical properties of kefir manufactured by a two-step fermentation. Korean Journal for Food Science of Animal Resources, 33(6), 744-751. doi:10.5851/ kosfa.2013.33.6.744

Yuliana, N. (2012). Kinetika pertumbuhan bakteri asam laktat isolat t5 yang berasal dari tempoyak. Jurnal Teknologi 63 Industri Hasil Pertanian, 13(2), 108-116. Retrieved from https://jurnal.fp.unila.ac.id/ index.php/JTHP/article/viewFile/72/80

Zajsek, K. \& Gorsek, A. (2010). Mathematical modelling of ethanol production by mixed kefir grains yeast population as a function of temperature variations. Biochemical Engineering Journal, 49(1), 7-12. doi:10. 1016/j.bej.2009.11.004

Zannini, E., Waters, D. M., Coffey, A. \& Arendt, E. K. (2016). Production, properties, and industrial food application of lactic acid bacteria-derived exopolysaccharides. Applied Microbiology and Biotechnology, 100(3), 1121-1135. doi:10 . 1007/s00253-015-7172-2 